\title{
Adhesion and invasion of bovine endothelial cells by Neospora caninum
}

\author{
A. HEMPHILL', B. GOTTSTEIN and H. KAUFMANN \\ Institute for Parasitology, University of Berne, Laenggass-Strasse 122, CH-3012 Berne, Switzerland
}

Received 23 March 1995 ; revised 4 fuly 1995 ; accepted 4 fuly 1995)

\begin{abstract}
SUM MARY
Neospora caninum is a recently identified coccidian parasite which was, until 1988, misdiagnosed as Toxoplasma gondii. It causes paralysis and death in dogs and neonatal mortality and abortion in cattle, sheep, goats and horses. The life-cycle of Neospora has not yet been elucidated. The only two stages identified so far are tissue cysts and intracellularly dividing tachyzoites. Very little is known about the biology of this species. We have set up a fluorescence-based adhesion / invasion assay in order to investigate the interaction of $N$. caninum tachyzoites with bovine aorta endothelial (BAE) cells in vitro. Treatment of both host cells and parasites with metabolic inhibitors determined the metabolic requirements for adhesion and invasion. Chemical and enzymatic modifications of parasite and endothelial cell surfaces were used in order to obtain information on the nature of cell surface components responsible for the interaction between parasite and host. Electron microscopical investigations defined the ultrastructural characteristics of the adhesion and invasion process, and provided information on the intracellular development of the parasites.
\end{abstract}

Key words: Apicomplexa, adhesion, invasion, cell adhesion molecules, cytoskeleton.

\section{INTRODUCTION}

Neospora caninum is an obligatory intracellular parasite which is structurally very similar to Toxoplasma gondii, and has been misdiagnosed as such until 1988. $N$. caninum was first isolated from a dog where it caused severe neurological problems, paralysis and death (Dubey et al. 1988). Other structurally and antigenically similar parasites have been reported from sheep, goats and horses, and in cattle $N$. caninum is now regarded as a major cause of neonatal mortality and abortion (Barr et al. 1994). Based on DNA sequence analysis, the parasite has been placed into the family Sarcocystidae and is established as a sister group to $T$. gondii in the phylum Apicomplexa (Ellis et al. 1994). The only two stages of its (largely unknown) life-cycle discovered to date are dividing tachyzoites and tissue cysts. $N$. caninum produces grossly visible necrotic lesions in a few days p.i., and causes cell death by intracellular multiplication of tachyzoites. In infected animals, tachyzoites have been found in neural cells, macrophages, fibroblasts, vascular endothelial cells, and hepatocytes. In vitro cultivation of tachyzoites has been achieved using several well-established cell lines (Lindsay \& Dubey, 1989; Dubey \& Lindsay, 1993), and infected cultured cells were used to compare the ultrastructural features of $N$. canimum and T. gondii (Lindsay et al. 1993). Tachyzoites obtained from cell cultures retain their infectivity for animals (Dubey \& Lindsay, 1993).

An important pre-requisite for entry, survival and proliferation of obligatory intracellular parasites is recognition of the appropriate host cell. This initial physical contact, which is likely to be mediated by one or several specific cell surface molecules, triggers the invasive process, determines the strategy for evading the phagolysosomal system of the host cell, and is also important with respect to the metabolic changes which occur within the parasite and the host. However, entry and development of obligate intracellular parasites takes place by employing a variety of mechanisms, either with or without the participation of the host cells. Detailed studies on various aspects of host-parasite interactions have been carried out on intracellular parasites such as Plasmodium spp. (Bannister \& Dluzewski, 1990; Pasvol, Carlsson \& Clough, 1992; Holder, 1994), Eimeria spp. (Augustine, 1989; Chobotar, Danforth \& Entzeroth, 1993), Theileria parva (Fawcett, Musoke \& Voigt, 1984; Shaw, Tilney \& Musoke, 1991), Toxoplasma gondii (Werk, 1985 ; Bonhomme, Pingret \& Pinon, 1992; Joiner \& Dubremetz, 1993; Kasper \& Mineo, 1994), and the South American trypanosomatids Leishmania spp. (Wilson et al. 1992) and Trypanosoma cruzi (Cross \& Tackle, 1993; Schenkman \& Eichinger, 1993).

The current information on the basic biology of $N$. caninum is sparse, and detailed investigations on the nature of Neospora tachyzoite-host cell interaction on the molecular level have not been carried out to date. The aim of the study described in this paper was therefore to dissect the interaction between cultured $N$. caninum tachyzoites and bovine 
aorta endothelial (BAE) cells in vitro, a process which resembles the interaction between parasites and vascular endothelial host cells in vivo. An in vitro adhesion / invasion assay was characterized, where observations were made using light- and transmission electron microscopy. Biochemical inhibition experiments were performed to investigate the reactive groups which take part in the interaction.

\section{MATERIALS AND METHODS}

If not otherwise stated, all reagents and tissue culture media were purchased from Sigma (St Louis, Mo, USA)

\section{Endothelial cells}

Primary cultures of bovine aorta endothelial (BAE) cells were prepared as described by Gray et al. (1985) and were maintained in $8-10 \mathrm{ml}$ of RPMI-medium (Gibco) supplemented with $20 \%$ foetal calf serum (FCS), $2 \mathrm{~mm}$ glutamine, $50 \mathrm{U} / \mathrm{ml}$ penicillin, and $50 \mu \mathrm{g} / \mathrm{ml}$ streptomycin at $37^{\circ} \mathrm{C} / 5 \% \mathrm{CO}_{2}$ in $\mathrm{T}-25$ tissue culture flasks. Cultures between passages 11 and 20 were used. For adhesion / invasion experiments, BAE cells were grown on glass coverslips in 24-well tissue culture plates (Sarstedt, USA) until 60-80\% confluency. Monolayers were used either unfixed, or they were fixed for $10 \mathrm{~min}$ at $4^{\circ} \mathrm{C}$ in PBS containing either $1 \%$ or $3 \%$ paraformaldehyde, or a mixture of $3 \%$ paraformaldehyde / $0.05 \%$ glutaraldehyde. In some experiments, monolayers were fixed in $2 \%$ glutaraldehyde in PBS for 2-4 min, rinsed extensively in PBS, and then stored in $0.16 \mathrm{M}$ ethanolamine, $\mathrm{pH} 8 \cdot 3$, for $24 \mathrm{~h}$ at $4{ }^{\circ} \mathrm{C}$ (Hemphill, Frame \& Ross, 1994). Prior to use, coverslips were rinsed extensively with PBS.

\section{Parasites}

Neospora caninum tachyzoites of the Nc-1 isolate (Dubey et al. 1988; Lindsay, Blagburn \& Dubey, 1990) were maintained in BAE-cell monolayers at $37^{\circ} \mathrm{C} / 5 \% \mathrm{CO}_{2}$ in RPMI-medium containing $2 \mathrm{mM}$ glutamine, $50 \mathrm{U} / \mathrm{ml}$ penicillin, $50 \mu \mathrm{g} / \mathrm{ml}$ streptomycin, and $7 \%$ FCS. Parasites were harvested from their feeder cell cultures when about $60-80 \%$ of the BAE host cells were lysed overnight (typically 3-4 days p. i.). Free tachyzoites were removed from the tissue culture flasks by collecting the medium supernatant, and a large portion of the residual parasites were released from their feeder cells by vigorously striking the side of the flask 2-3 times. Alternatively, they were scratched off using a rubber policeman. A few $\mathrm{ml}$ of medium were added, and the tachyzoites were collected. The preparation (containing tachyzoites and host cell debris) was washed twice in cold PBS. The final pellet was resuspended in $2 \mathrm{ml}$ of cold PBS and passed through a PD-10 ${ }^{\mathrm{TM}}$ column filled with Sephadex G25M (Pharmacia), previously equilibrated with PBS. The eluted, purified, parasites were centrifuged at $4^{\circ} \mathrm{C}$ and were resuspended in cold RPMI or PBS, depending on the experiments to be performed (see below). Purified tachyzoites were checked for viability using Trypan blue staining $(0.25 \%$ in PBS), and only preparations containing at least $95 \%$ or more viable parasites were immediately used for adhesion assays.

\section{Production of polyclonal rabbit anti-N. caninum antiserum}

Prior to immunization of a rabbit, the pre-immune serum was taken, and the absence of antibodies directed against $T$. gondii and $N$. caninum was confirmed by indirect immunofluorescence (Seefeldt, Kirkbride \& Dubey, 1989; Trees, Tennant \& Kelly, 1991). The serologically negative rabbit was infected intravenously with $10^{7}$ freshly purified, living, $N$. caninum tachyzoites, and $10^{8}$ tachyzoites were administred orally. This procedure was repeated 2 times at intervals of 10 days, before the serum was taken. The rabbit showed no clinical signs throughout the immunization period.

\section{In vitro adhesion / invasion assay}

Freshly purified $\boldsymbol{N}$. caninum, either untreated parasites, or tachyzoites treated according to the experiments described below, were adjusted to $5 \times 10^{7}$ parasites / $\mathrm{ml}$ in RPMI / $1 \% \mathrm{FCS}$. One $\mathrm{ml}$ was then incubated at $37^{\circ} \mathrm{C} / 5 \% \quad \mathrm{CO}_{2}$ with $\mathrm{BAE}$ cell monolayers grown on glass coverslips in 24-well tissue culture plates. After $40 \mathrm{~min}$, coverslips were rinsed 3 times in PBS, and were placed into fixation buffer containing PBS / 3\% paraformaldehyde / $0.05 \%$ glutaraldehyde for $10 \mathrm{~min}$ at $24^{\circ} \mathrm{C}$. Coverslips were then rinsed extensively in PBS and were subsequently incubated in PBS containing $1 \% \mathrm{BSA}$ and $50 \mathrm{~mm}$ glycine (blocking buffer) for $30 \mathrm{~min}$. The first antibody-layer (polyclonal rabbit anti- $N$. caninum) was applied at a dilution of $1: 200$ in blocking buffer for $25 \mathrm{~min}$, followed by 3 buffer rinses and an incubation in a $1: 100$ dilution in blocking buffer of a second antibody (goat anti-rabbit conjugated to Texas red, Becton Dickinson Immunocytometry Systems) for $25 \mathrm{~min}$. Specimens were then rinsed in PBS ( 3 times, $5 \mathrm{~min}$ ), and were placed into precooled methanol and acetone $\left(-20^{\circ} \mathrm{C}\right)$ for $5 \mathrm{~min}$ each. This step fixed the cells, the parasites, and the antibodies by precipitation onto the coverslip, and permeabilized the monoloayers as well. After rehydration ( $5 \mathrm{~min}$ in 3 changes of PBS each) the coverslips were placed into blocking buffer again $(30 \mathrm{~min})$, and intracellular parasites were labelled 
with the same polyclonal anti- $N$. caninum antiserum diluted as before. The secondary antibody for the detection of intracellular parasites was a goat antirabbit conjugated to FITC (The Binding Site). Specimens were then rinsed in $2 \times$ concentrated PBS for $1 \mathrm{~min}$, followed by additional rinses $(5 \times 5 \mathrm{~min}$ ) in PBS. In some experiments, the coverslips were subsequently stained with the DNA-specific dye Hoechst $33258(25 \mu \mathrm{g} / \mathrm{ml}$ in PBS) for $2 \mathrm{~min}$. Finally, the preparations were briefly rinsed in distilled water, and were embedded in a mixture of glycerol / gelvatol containing 1,4-diazobicyclo(2.2.2)octan (Merck) as an anti-fading reagent (Hemphill, Affolter \& Seebeck, 1992).

Results were obtained by inspection of 20 randomly chosen fields at $40 \times$ magnification on a Leitz Laborlux $S$ fluorescence microscope using all three channels. Counting of the Hoechst 33258-stained host cell nuclei indicated the number of host cells within a given field. The overall number of $N$. caninum tachyzoites was determined by counting the number of FITC-labelled parasites within the same field. Finally, the number of parasites sitting on the surface of the host cells was determined by counting the Texas red immunolabelled tachyzoites. From these three figures, we could determine (i) the percentage of the total parasite number / host cell in relation to a control experiment performed with the same parasite- and BAE cell-preparations on the same day, and (ii) the percentage of intracellular parasites in relation to the total parasite number in a given experiment.

In the case of adhesion / invasion inhibition assays (where either parasites or host cells were pre-treated with various chemicals prior to adhesion and invasion), results are presented as adhesion and invasion indices. The adhesion or invasion index of a given experiment was calculated by dividing the number of total or invaded parasites / cell by the number of total or invaded parasites / cell in a control experiment. All experiments were performed in duplicate. The data presented show the mean count from 1 representative experiment out of 4-6 carried out. For every experiment the deviation of adhesion and invasion indices was never more than $+0 \cdot 15$.

Time-course experiments of $\mathrm{N}$. caninum interactions with $B A E$ cells

The kinetics of parasite attachment, invasion and further parasite development were investigated by using the immunofluorescence staining protocol described above. Freshly purified parasites were incubated with BAE cell monolayers at $37^{\circ} \mathrm{C} / 5 \%$ $\mathrm{CO}_{2}$. After different time-points, duplicate coverslips of each were rinsed 3 times in PBS, and fixation and triple-labelling was carried out as described above.

\section{Transmission electron microscopy (TEM)}

Cultures containing endothelial cells grown in tissue culture flasks were infected with $N$. caninum tachyzoites for the different time-points as indicated in the text and the preparations were processed for thinsection TEM as follows. Cells were fixed in $2 \%$ glutaraldehyde $/ 0.2 \%$ tannic acid in $0.1 \mathrm{M}$ cacodylate buffer (Fluka Chemicals, UK), $\mathrm{pH} 7 \cdot 3$, for $2 \mathrm{~h}$ at room temperature. They were post-fixed with $1 \%$ osmium tetroxide in veronal acetate buffer, $\mathrm{pH} 7 \cdot 4$, for $1 \mathrm{~h}$ at $4{ }^{\circ} \mathrm{C}$, followed by buffer rinses. The fixed cells were then scraped from the surface of the tissue culture flask with a rubber policeman, and were then carried through a graded series of ethanol $(70 \%-95 \%-100 \%)$ and embedded in Epon 812 resin (Fluka Chemicals, Switzerland). After polymerizing the resin at $65^{\circ} \mathrm{C}$ for $24 \mathrm{~h}$, ultrathin sections were cut using a Diatom diamond knife on an LKB-ultramicrotome. Sections were loaded onto 200 mesh copper or nickel grids and stained with uranyl acetate and lead citrate (Smith \& Croft, 1991). Specimens were viewed on a Jeol 100 CX II transmission electron microscope operating at 60 $80 \mathrm{kV}$.

\section{Treatments of pre-fixed endothelial cells}

Monolayers were fixed in PBS containing $3 \%$ paraformaldehyde / $0.05 \%$ glutaraldehyde for $10 \mathrm{~min}$. This fixation completely prevented parasite entry into host cells. Coverslips were then washed several times in PBS before given the following treatments which would mainly alter the carbohydrate composition on the surface. (i) Periodate treatments (2-20 mM in either PBS ( $\mathrm{pH}$ adjusted to 7) or in $50 \mathrm{~mm}$ sodium acetate, $100 \mathrm{~mm} \mathrm{NaCl}, \mathrm{pH} \mathrm{5}$ ) were carried out as previously described (Hemphill et al. 1994). (ii) Both live and pre-fixed monolayers were rinsed twice in $20 \mathrm{~mm}$ MES-buffer, $100 \mathrm{~mm}$ $\mathrm{NaCl}, 4 \mathrm{mM} \mathrm{CaCl}$, pH 5.5 and were incubated with the same buffer containing $5 \mathrm{U} / \mathrm{ml}$ of neuraminidase type $\mathrm{V}$ from Clostridium perfringes (Hemphill et al. 1994) or with $0.5 \mathrm{IU} / \mathrm{ml}$ of neuraminidase from Vibrio cholerae (Calbiochem) for $60 \mathrm{~min}$ at $37^{\circ} \mathrm{C}$ (de Carvalho, Yan \& de Souza, 1993). (iii) Hyaluronidase digestion of monolayers was performed by incubating coverslips for $60 \mathrm{~min}$ at $37^{\circ} \mathrm{C}$ in RPMI containing $0.3 \mathrm{mg} / \mathrm{ml}$ of hyaluronidase from bovine testes (de Carvalho et al. 1993). (iv) The effects of pre-incubation of endothelial cell surface with lectins was studied by incubating coverslips with $50 \mu \mathrm{g} / \mathrm{ml}$ of the following lectins for $30 \mathrm{~min}$ in PBS: wheat germ agglutinin (WGA), specific for $N$-acetylglucosamine and $N$-acetyl-neuraminic acid residues, Tetragonobulus purpurea agglutinin (TPA), specific for fucosyl residues, Concanavalin $A$ (Con A), specific for $D$-mannosyl residues and $D$-glucosyl residues, and soybean agglutinin (SBA), specific for 
$N$-acetyl-galactosamine. Incubations were followed by a brief fixation step ( $5 \mathrm{~min}, 1 \%$ paraformaldehyde in PBS) and extensive washing with PBS prior to incubations with $N$. caninum tachyzoites.

\section{Treatments of live $B A E$ cell monolayers prior to the adhesion / invasion assay}

Monolayers were incubated with cycloheximide $\left(50 \mu \mathrm{g} / \mathrm{ml}\right.$ in culture medium) for $6 \mathrm{~h}$ at $37^{\circ} \mathrm{C}$, or with tunicamycin $(2.5 \mu \mathrm{g} / \mathrm{ml})$ for $4 \mathrm{~h}$ at $37^{\circ} \mathrm{C}$ (Hemphill et al. 1994). The effect of glycolytic inhibition of endothelial cells was assayed by preincubating with $100 \mathrm{~mm}$ deoxyglucose in PBS. Mitochondrial inhibitors used were sodium azide (1-5 mM), antimycin (10-100 $\mathrm{nM})$ and oligomycin $(1-5 \mu \mathrm{M})$, all solubilized in PBS $/ 0.5 \%$ BSA. The effects of altering the microtubule network within endothelial cells were assessed by treating cells with nocodazole $(0.5 \mu \mathrm{g} / \mathrm{ml})$ or taxol $(5 \mu \mathrm{g} / \mathrm{ml})$ respectively in culture medium for $1 \mathrm{~h}$ at $37^{\circ} \mathrm{C}$. Cytochalasin $\mathrm{D}(0 \cdot 1-50 \mu \mathrm{M})$ was added to the culture medium in order to study the effects of alterations of the actin microfilament system.

Pre-treatments of N. caninum tachyzoites prior to interaction with $B A E$ cells

Freshly isolated tachyzoites were given the following treatments prior to performing the adhesion/ invasion assay.

Extracellular maintenance. $N$. caninum were resuspended in RPMI / $1 \% \mathrm{FCS}$ and incubated either at $37{ }^{\circ} \mathrm{C}$ or at $4^{\circ} \mathrm{C}$. After various time-points $10^{7}$ parasites were assayed for adhesion and invasion as described above.

Pre-fixation. Tachyzoites were fixed by addition of $1 \%$ glutaraldehyde or $3 \%$ paraformaldehyde to the medium for 5 and $15 \mathrm{~min}$, respectively, at $4{ }^{\circ} \mathrm{C}$. They were washed twice in PBS and kept in 0.16 M ethanolamine, $\mathrm{pH} 8 \cdot 3$, at $4^{\circ} \mathrm{C}$ overnight. After 3 washes in PBS, tachyzoites were resupended in RPMI / $1 \%$ FCS and were assayed for adhesion and invasion at a density of $5 \times 10^{7}$ parasites $/ \mathrm{ml}$.

Drug treatments. Tachyzoites were incubated in PBS $/ 1 \% \mathrm{FCS}$ in the presence of $100 \mathrm{~mm}$ deoxyglucose for $30 \mathrm{~min}$ at $24^{\circ} \mathrm{C}$. Sodium azide $(1-20 \mathrm{~mm})$, antimycin (1-100 nM) and oligomycin (1-5 $\mu \mathrm{M})$ were used to study the effects of mitochondrial inhibitors. The protein kinase inhibitor $\mathrm{H} 8$ was used at $10^{-3}-10^{-9} \mathrm{M}$ in PBS / $1 \%$ FCS for $30 \mathrm{~min}$ at $24^{\circ} \mathrm{C}$ (Schenkman, Robbins \& Nussenzweig, 1991 a).
Cycloheximide treatment was carried out at $30 \mu \mathrm{g} / \mathrm{ml}$ for $3 \mathrm{~h}$, and tunicamycin was added to tachyzoites at $1 \mu \mathrm{g} / \mathrm{ml}$ for $3 \mathrm{~h}$ at $37^{\circ} \mathrm{C}$ in culture medium. Taxol $(10 \mu \mathrm{g} / \mathrm{ml})$, nocodazole $(1 \mu \mathrm{g} / \mathrm{ml})$, and cytochalasin $D(5-100 \mu \mathrm{M})$ were incubated with tachyzoites in culture medium for $60 \mathrm{~min}$ at $37^{\circ} \mathrm{C}$. After all these treatments, tachyzoites were washed twice with cold PBS, and adjusted to $10^{7}$ parasites/ml in RPMI / 1\% FCS.

Temperature. BAE cells and parasites were precooled at $4^{\circ} \mathrm{C}$ in RPMI / $1 \% \mathrm{FCS}$ for $20 \mathrm{~min}$.

Surface protease treatments. Freshly purified tachyzoites were incubated in PBS containing either trypsin protease type VI, pronase (both Serva, UK) or chymotrypsin (Sigma), all at $10 \mu \mathrm{g} / \mathrm{ml}$. After an incubation at $37^{\circ} \mathrm{C}$ for $20 \mathrm{~min}$, the cells were put on ice, and the reactions terminated by the addition of $20 \%$ FCS and incubation on ice. Tachyzoites were finally washed twice with cold PBS prior to use.

Periodate and lectin treatments. In order to remove potential surface-exposed carbohydrate residues, tachyzoites were resuspended in ice-cold PBS containing 2-5 $\mathrm{mM} \mathrm{NaIO}$, and incubated at $4{ }^{\circ} \mathrm{C}$ for $5 \mathrm{~min}$. Potential sugar residues on the surface of $N$. caninum were blocked by resuspending the tachyzoites in PBS containing $50 \mu \mathrm{g} / \mathrm{ml}$ of the lectins Con A, SBA, TPA and WGA. The parasites were incubated at $4{ }^{\circ} \mathrm{C}$ for $40 \mathrm{~min}$. with the lectins and then washed twice in PBS.

\section{RESCLTS}

\section{Kinetics of $\mathrm{N}$. caninum- $B A E$ cell interactions in vitro}

A crucial step during the (still largely unknown) lifecycle of $N$. caninum is its ability to adhere to, and invade, a variety of host cells. In order to study, and to be able to distinguish between, these two processes, we established and characterized an immunofluorescence-based in vitro adhesion / invasion assay, in which purified $N$. caninum tachyzoites were allowed to interact with BAE cell monolayers grown on glass coverslips. In order to detect adherent, noninvaded parasites, coverslips were fixed and surface labelled using a polyclonal antiserum directed against purified $N$. caninum tachyzoites, followed by a Texas red-conjugated second antibody. After this, the monolayers were permeabilized and incubated again with the polyclonal antiserum and a secondary antibody conjugated to FITC, thus demonstrating both intra- and extracellular parasites (Fig. 1). In no 

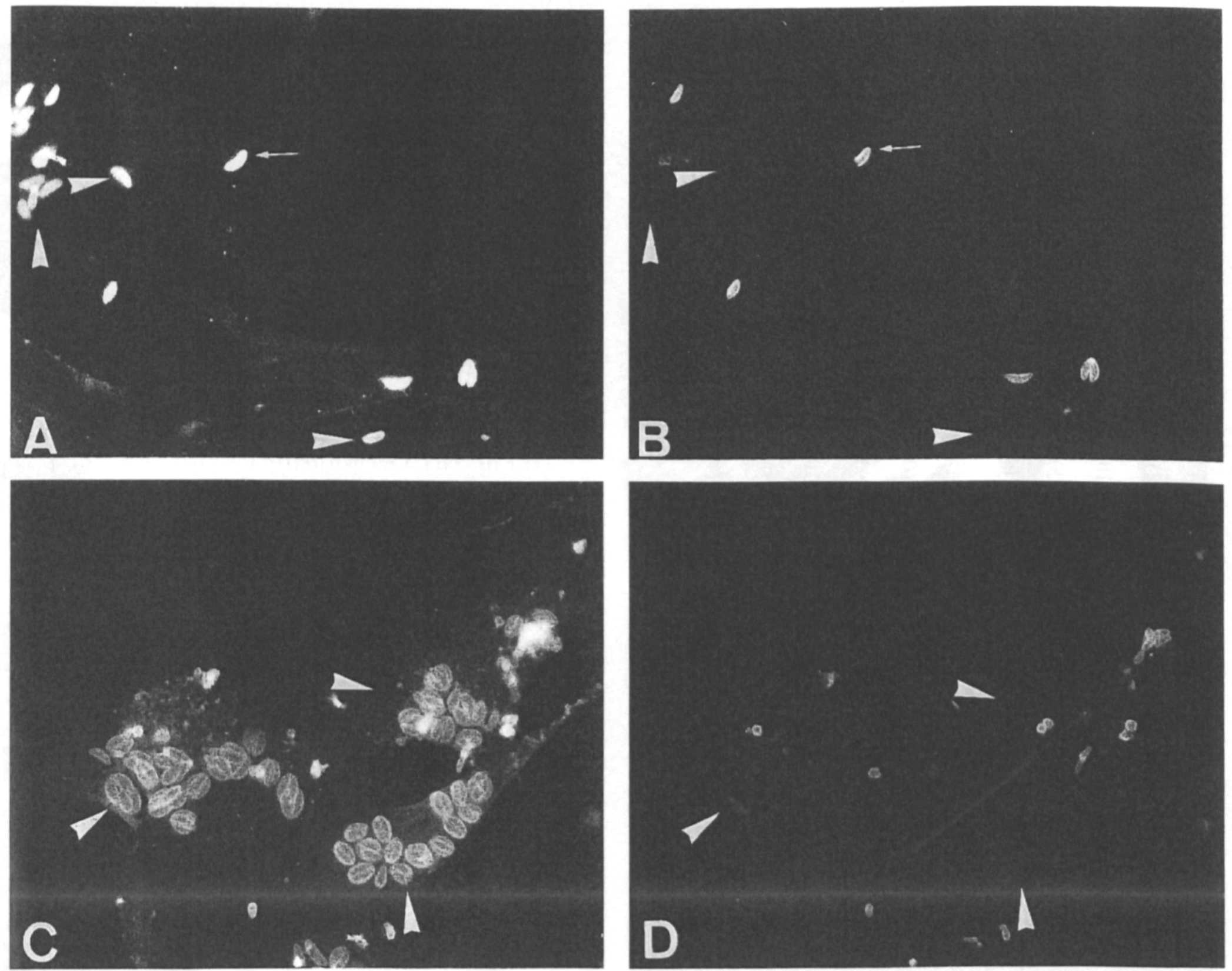

Fig. 1. Immunofluorescence assay carried out in order to demonstrate, and distinguish, between intra- and extracellular Neospora caninum tachyzoites. (A-B) Parasites and BAE cells incubated for 30 min prior to fixation. (C-D) Parasites and BAE cells cocultivated for $36 \mathrm{~h}$ prior to fixation. (A and C) All tachyzoites (FITC-labelling); (B and D) extracellular, adherent tachyzoites (Texas red-labelling). The arrow points at a tachyzoite which is in the process of invading the host cell, arrowheads indicate intracellular parasites.

case did the tachyzoites attach to the areas of the glass coverslip devoid of host cells. In addition, attachment and invasion of parasites was not uniform. Some cells contained several parasites, others none. We also found that this assay was capable of demonstrating parasites which were just in the process of invading a host cell (Fig. $1 \mathrm{~A}$ and $\mathrm{B}$ ).

The kinetics of attachment, invasion and in vitro development and proliferation of $N$. caninum tachyzoites within endothelial cell monolayers were evaluated using the assay described above (Fig. 2A). During incubation of tachyzoites with BAE cell monolayers, the total number of tachyzoites / host cell increased most rapidly within the first $60 \mathrm{~min}$. The further increase in overall parasite numbers was less dramatic. Already after 5 min p.i., intracellular parasites could be observed, and the percentage of intracellular parasites in relation to the total parasite number increased extensively during the first 20 $40 \mathrm{~min}$, reaching its highest figure after $60 \mathrm{~min}$ p.i. (Fig. 2A). At $120 \mathrm{~min}$ p.i. almost every endothelial cell had parasites bound onto its surface, but only about $65 \%$ of the cells were actually infected (Fig. 2A). Few tachyzoites undergoing endodyogeny were first observed after $6 \mathrm{~h}$, and their number increased steadily with time. After $36 \mathrm{~h}$, the overall number of parasites / host cell had almost doubled (Fig. $1 \mathrm{C}$ and D). At 60-72 h p.i., rupturing of the host cells was first observed, and fresh tachyzoites were set free which were weakly motile and exhibited gliding and flexing movements. These parasites would either become non-viable and were found in the supernatant together with host cell debris, or would infect neighbouring BAE cells.

The results obtained during the initial phases of this time-course experiment suggested that parasites were most infective during the first $60 \mathrm{~min}$ of incubation with endothelial cells. In order to find out whether extracellular maintenance of tachyzoites affected their infectivity, we incubated purified parasites in RPMI / $1 \% \mathrm{FCS}$ and let them interact with $\mathrm{BAE}$ cell monolayers only after different incubation times (Fig. 2B). Maintenance of tachyzoites at $37^{\circ} \mathrm{C}$ for longer than $46 \mathrm{~h}$ resulted in a 

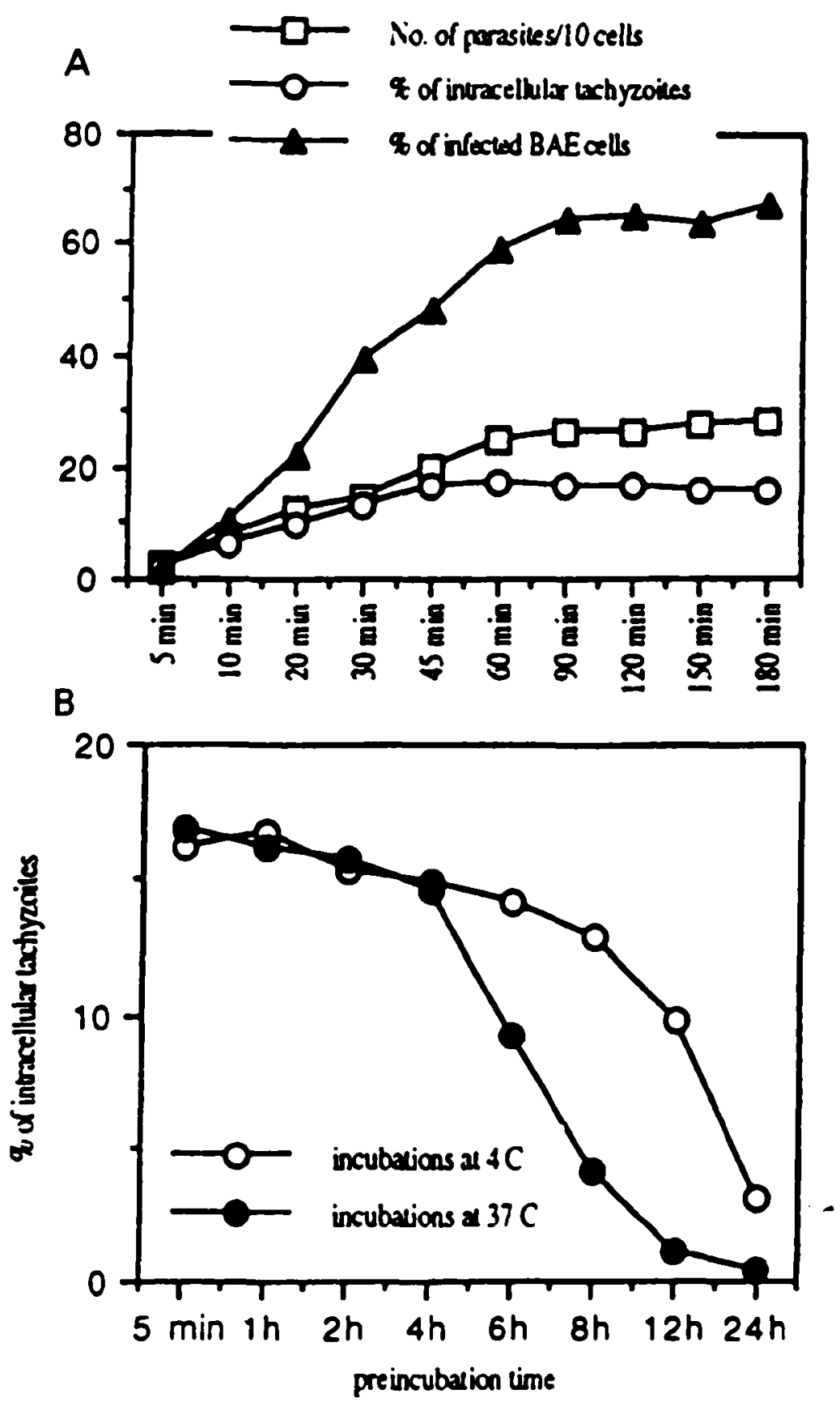

Fig. 2. Time-course experiments investigating the kinetic aspects of the initial Neospora-host cell interactions (A) Time-course of adhesion to, and invasion of, BAE cells by $N$. caninum tachyzoites. Note that adhesion to, and invasion of, host cells takes place mainly within the first $60 \mathrm{~min}$. (B) Time-course experiment demonstrating the effects of extracellular maintenance of tachyzoites at $37^{\circ} \mathrm{C}$ and $4{ }^{\circ} \mathrm{C}$.

relatively rapid decrease of infectivity with time, while parasites remained strongly infective for longer time periods (up to $12 \mathrm{~h}$ ) if kept at $4{ }^{\circ} \mathrm{C}$ (Fig. 2B). Thus, prolonged extracellular maintenance of tachyzoites had a significant negative impact on their infectivity.

Electron microscopical investigations of the adhesion, invasion and intracellular development of $\mathrm{N}$. caninum

According to the above 'time schedule', BAE cell monolayers grown in tissue culture flasks were infected with purified $N$. caninum tachyzoites, and after different time-points the cultures were fixed and processed for TEM (Figs. 3A-F, 4A-E). The initial contact between tachyzoites and endothelial cells appeared to be mediated by any part of the parasite surface, with no obvious preference for a specialized parasite cell surface domain. In addition, there was also no preferential contact area on the endothelial cell surface involved, since both pseudopodia- and non-pseudpodia containing surfaces were found to contain adherent parasites (Fig. 3A and B). The first step in the actual invasion process was the development of a recess in the host cell membrane right at the site of parasite interaction (Fig. 3C). As this junction expanded circumferentially from the point of initial contact, the parasite appeared to invade the host cell by progressive zippering of the membranes (Fig. 3D), until it was completely enclosed by a parasitophorous vacuole membrane (PVM, Fig. 3E). Occasionally we also found host cell pseudopodia which appeared to assist in the entry process, increasing the host-parasite contact area by engulfing the parasites (Fig. 3F). However, the PVM was in continuity with the host cell plasma-membrane during the whole entry process. Immediately after invasion, the parasitophorous vacuole would translocate from the extreme host cell periphery towards the host cell interior (Fig. 4A). Parasites then exhibited a great deal of surface membrane activity, which could indicate that parasite-specific material was secreted, modifying the vacuolar lumen and the PVM, as described for other intracellular parasites (Fig. 4B and C). When a host cell was infected with multiple numbers of parasites (Fig. 4C) each tachyzoite had its own PVM where it could develop and undergo endodyogeny already after $6 \mathrm{~h}$ post-invasion (Fig. 4D). However, it is likely that, during the final stages of intracellular development of $N$. caninum, the PVM disintegrated before lysis of the host cell could occur (Fig. 4E).

\section{The effects of pre-fixation, metabolic inhibition and cytoskeletal alterations of endothelial cells on their interaction with $\mathrm{N}$. caninum.}

Endothelial monolayers grown on glass coverslips were treated with paraformaldehyde (1-3\%), glutaraldehyde $(0.05-2 \%)$ and mixtures thereof. The effects of these treatments on attachment and invasion of tachyzoites were evaluated with respect to control experiments with untreated host cells (Fig. 5). Pre-fixation of monolayers with both aldehydes had a profound effect on the overall number of tachyzoites / cell, reducing it to aproximately $25 \%$ compared to unfixed host cells. However, invasion of host cells was only completely inhibited when glutaraldehyde $(0.05 \%)$ was incorporated into the fixation solution. No differences with respect to adhesion of the parasites were observed when higher concentrations of glutaraldehyde (up to $2 \%$ ) were used.

However, the fact that $N$. caninum also invaded paraformaldehyde-fixed host cells, although at a much lower rate, suggested that the parasite actively 

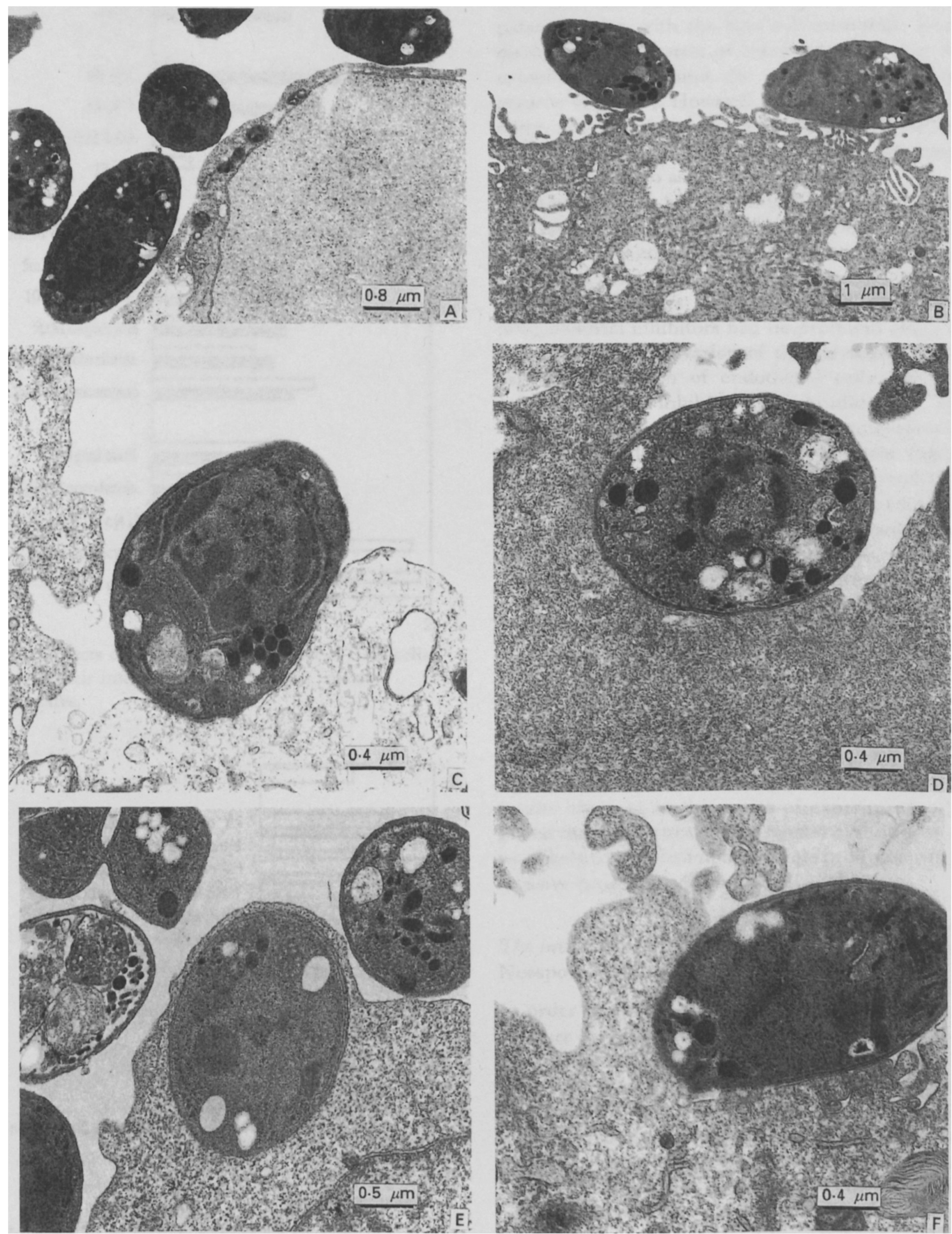

Fig. 3. (A-F) TEM of the initial host-parasite interaction and invasion of BAE cells. Note that the initial contact between BAE cells and tachyzoites is not likely to be mediated by any specialized cell surface domains (A, B). The initial phase of the invasive process is characterized by an indentation on the BAE cell surface membrane at the site of the host-parasite contact (C), followed by progressive zippering of the two membranes (D), until the entire parasite is enclosed by a parasitophorous membrane (E). BAE cell pseudopodia occasionally assist in the invasive process by engulfing the parasite $(F)$. 

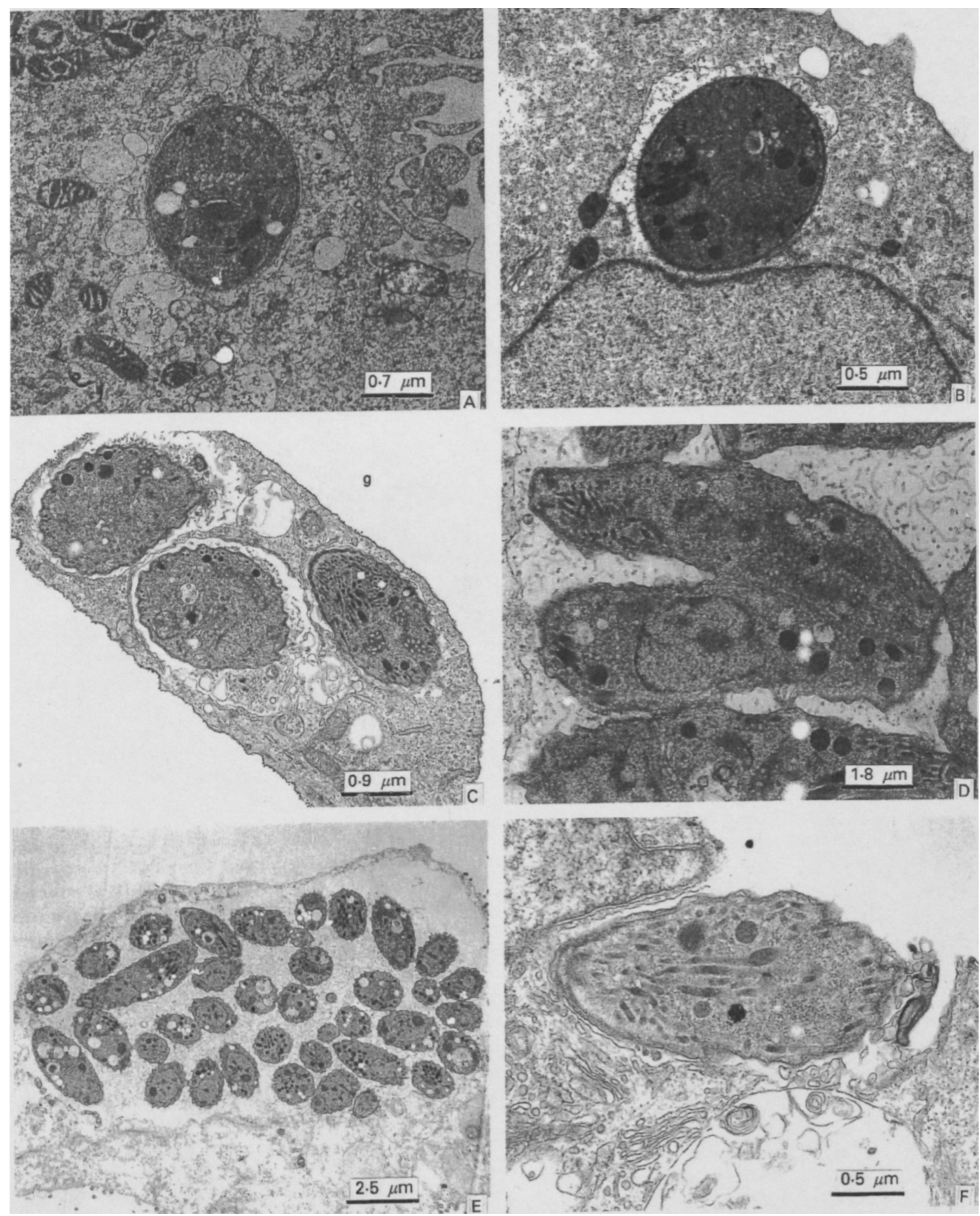

Fig. 4. (A-F) TEM of the intracellular development of Neospora caninum tachyzoites. As the entry process is completed, the tachyzoites are entirely surrounded by a parasitophorous vacuole membrane (PVM), which is in close contact with the parasite cell surface (A). Shortly after entry, parasites exhibit membrane activity (B), thus probably modifying the PVM and constructing their own compartment, the parasitophorous vacuole, in order to achieve suitable conditions for further development. Each parasite has got its own vacuole (C). Endodyogeny occurs first after $6 \mathrm{~h}$ (D), thus continuing until larger pseudocysts are developed which eventually lead to rupture of the host cell after 3-4 days (E). N. caninum tachyzoite in the process of invading a formaldehyde-fixed BAE cell (F). Note the extensive damage on the BAE cell surface, and the extensive membrane activity surrounding the advancing tachyzoite. 


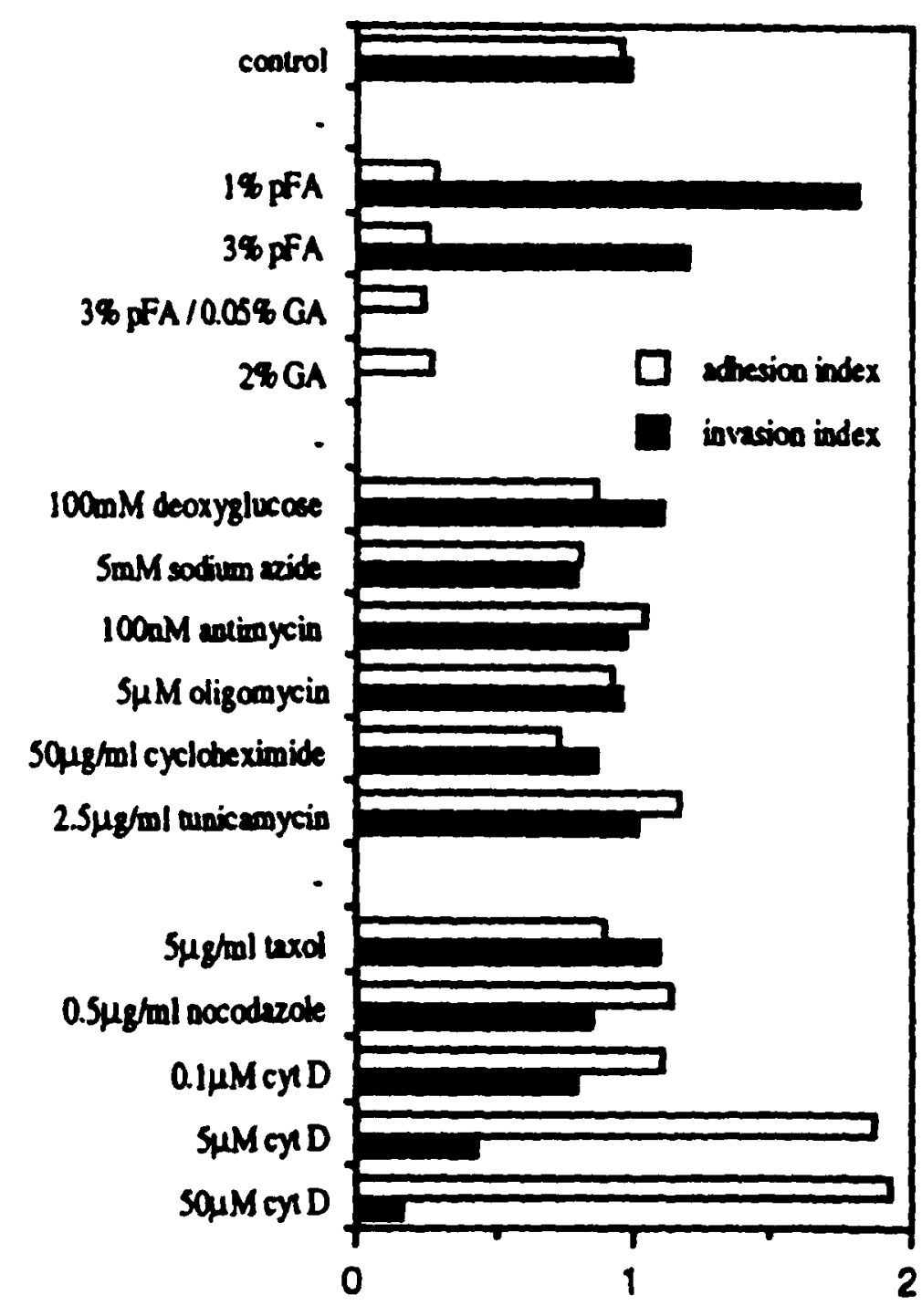

Fig. 5. Effects of various pre-treatments of BAE cells prior to their interaction with Neospora caninum tachyzoites.

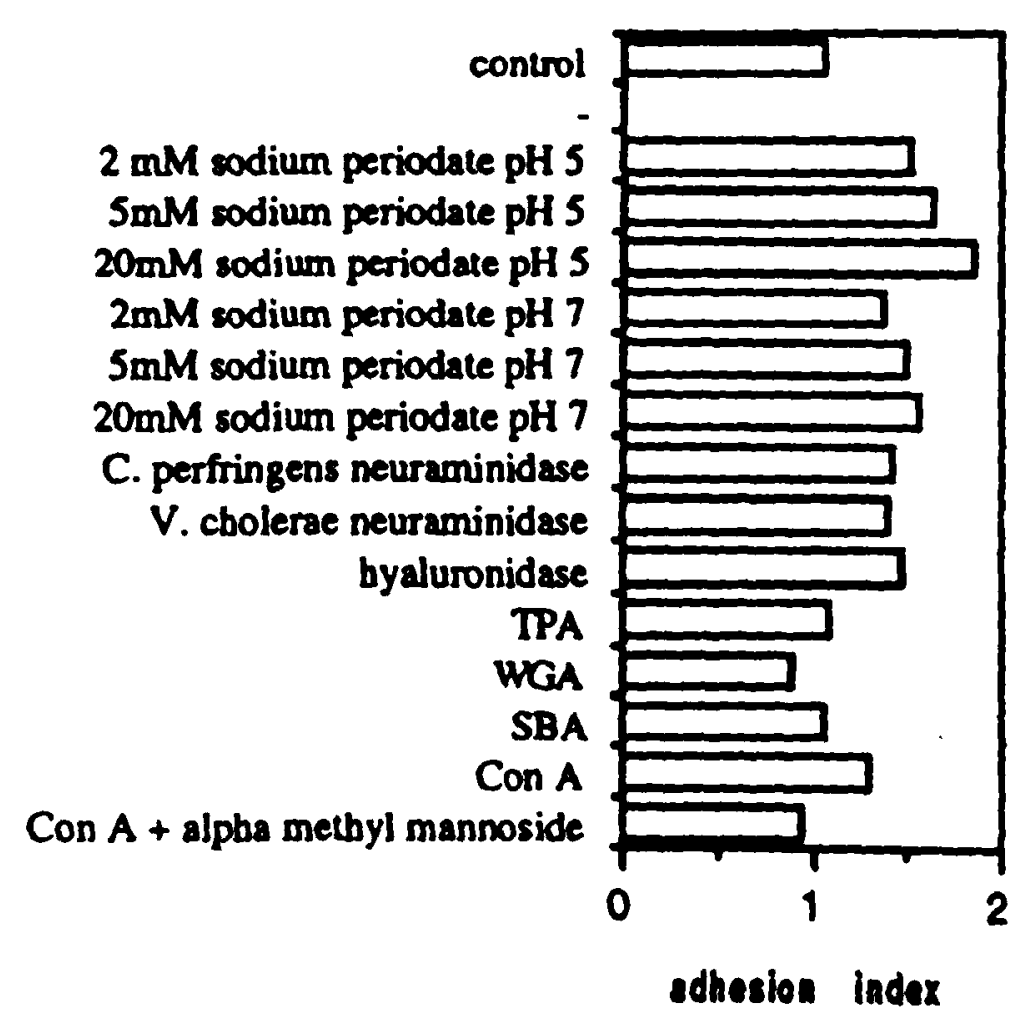

Fig. 6. Effects of various treatments altering the carbohydrate composition of pre-fixed $(3 \%$ paraformaldehyde / $0.05 \%$ glutaraldehyde) BAE cells on adhesion of Neospora caninum tachyzoites.

participated in this process. Electron microscopical investigations of parasites invading formaldehydetreated host cells suggested that, at least at the ultrastructural level, this invasive process differed somewhat from the entry process into live cells:
BAE-cells showed dramatic changes at the point of parasite entry, with the host cell membrane being disrupted, and clusters of vesicles appearing in the cytoplasm and around the advancing tip of the parasite (Fig. 4F). However, it appeared that, after entry, the tachyzoites were unaccessible for the first antibody layer in the immunofluorescence-based adhesion/invasion assay.

Invasion of pre-fixed, non-metabolizing host cells suggested a rather passive role of the endothelial cells during parasite entry. Thus, we also investigated the effects of pre-incubation of BAE cells with several metabolic inhibitors (Fig. 5). Both glycolytic and mitochondrial inhibitors had no profound effect on the adhesion and invasion of the parasites, neither had pre-incubation of endothelial cells with the protein synthesis inhibitor cycloheximide (Fig. 5).

Pre-incubation of the BAE cell monolayers with the microtubule active drugs nocodazole (which induces depolymerization of microtubules) and taxol (which stabilizes microtubules and induces extensive polymerization and microtubular rearrangement) had no significant effect, neither on adhesion nor on invasion of $N$. caninum (Fig. 5). However, treatment of BAE cells with cytochalasin D, a drug which induces gross changes within the actin microfilament system was very effective (Fig. 5). While the total number of parasites / cell was significantly higher than in control experiments, they were only adhering to the host cell surface. Thus, invasion of tachyzoites was almost completely inhibited in cytochalasin D. treated host cells in a dose-dependent manner. The results obtained in this series of experiments suggested that the cortical actin skeleton of the host cells was likely to play an important role in triggering the invasive process in $N$. caninum.

\section{The involvement of host cell surface carbohydrates in Neospora adhesion}

In order to study the involvement of carbohydrate residues on the endothelial cell surface in adhesion, pre-treatment of endothelial monolayers was carried out employing reagents which would alter their cell surface carbohydrate composition. Since alterations of cell surface carbohydrates was often accompanied by detachment of monolayers from the surface they adhered to (most cell adhesion molecules are composed of carbohydrate residues), we performed these experiments using BAE cells pre-fixed in $3 \%$ paraformaldehyde / $0.05 \%$ glutaraldehyde. Thus parasites would attach to, but not invade, BAE cells. Periodate treatments carried out at neutral or low $\mathrm{pH}$ resulted in increased adhesion of tachyzoites to their host cells (Fig. 6). Similar effects were observed when endothelial cells were pre-treated with neuraminidase and hyaluronidase. In contrast, preincubation of monolayers with the lectins WGA, SBA and TPA had no effect on adhesion of the 


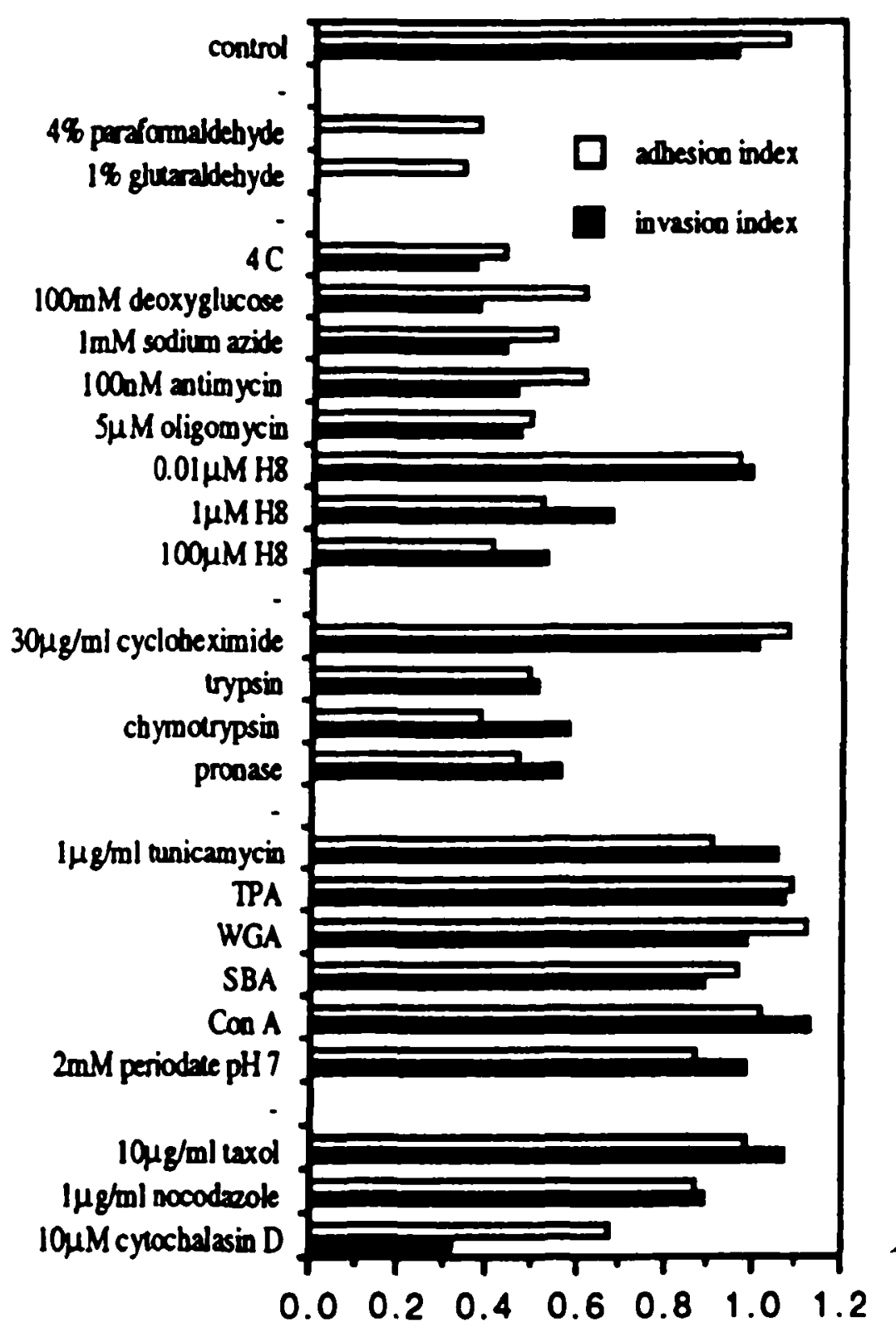

Fig. 7. Effects of pre-treatments of Neospora caninum tachyzoites on their potential to adhere to, and invade, BAE cells.

parasites, while Con A treatment resulted in a slight increase in parasite attachment (Fig. 6). However, the addition of the Con $A$-inhibiting sugar alphamethyl mannoside $(200 \mathrm{~mm})$ to Con A prevented increased parasite binding, while addition of this sugar to the parasites during the binding assay did not (Fig. 6). Thus, the parasites bound to a part of the Con A molecule different from the sugar binding site. In conclusion, carbohydrates on the endothelial cell surface inhibit rather than promote the adhesion of $N$. caninum.

\section{Effects of pre-treatments of $\mathrm{N}$. caninum tachyzoites}

Pre-fixed parasites completely lost the ability to invade endothelial cells (Fig. 7). However, a considerable percentage of the parasites $(35 \%$ compared to the control experiment) was still found to adhere to the monolayers. This suggested that, although the initial contact between parasite and host could lead to tachyzoite adhesion without energy expenditure, the entry process itself required metabolic energy on part of the parasite.

In a further series of experiments, tachyzoites were resuspended in various buffers and media, and were then allowed to adhere to and invade BAE cell monolayers. No significant differences were found when parasites were resuspended in culture medium containing RPMI / 7\%FCS, RPMI / 1\%FCS, RPMI alone, PBS / $50 \mathrm{~mm}$ glucose or PBS alone (data not shown). Carrying out the binding assay at $4{ }^{\circ} \mathrm{C}$, however, resulted in decreased adhesion and dramatically diminished invasion of host cells (Fig. 7). Similar results were obtained when parasites were pre-treated with a glycolytic inhibitor (deoxyglucose), or with mitochondrial inhibitors such as sodium azide, antimycin and oligomycin. Preincubation of $N$. caninum tachyzoites with a protein kinase inhibitor, $\mathrm{H8}$, also resulted in partial inhibition of both the adhesion and invasion process (Fig. 7).

When tachyzoites were treated with cycloheximide prior to the incubation with BAE cells, no effect could be observed. However, surface protease treatments using low concentrations of trypsin, pronase and chymotrypsin significantly interfered with the ability of the parasites to adhere to, and invade, BAE cells (Fig. 7). Pre-incubating parasites with tunicamycin, an inhibitor of $N$-glycosylation, was also ineffective. Altering the parasite cell surface carbohydrates by treating tachyzoites with $2 \mathrm{~mm}$ sodium periodate in PBS for $5 \mathrm{~min}$ at $4{ }^{\circ} \mathrm{C}$ did not affect their infectivity (Fig. 7), nor did pre-incubations of the tachyzoites with lectins (data not shown).

$N$. caninum tachyzoites were also incubated with drugs which would affect the function of the cytoskeleton, to investigate whether it was involved in mammalian cell interaction (Fig. 7). Neither taxol, which enhances and stabilizes microtubules, nor nocodazole, a microtubule depolymerizing drug, had any effect on adhesion and invasion. However, treatments of parasites with cytochalasin D, an actin depolymerizing drug, resulted in a marked decrease in adhered and invaded parasites. Thus, the actin skeleton of $N$. caninum is likely to play an important role during infection of host cells.

\section{DISCUSSION}

In this study, the in vitro interaction between $N$. caninum and bovine aorta endothelial cells was investigated. To demonstrate and quantitate $N$. caninum adhesion, invasion, and development, we modified an assay described by Schenkman et al. $(1991 a)$ in order to clearly distinguish between intracellular and extracellular parasites by fluorescence light microscopy. Our observations were extended using transmission electron microscopy of BAE cell cultures infected with $N$. caninum.

Under the conditions used for our experiments, both adhesion and invasion took place within a relatively short time after incubation of the tachyzoites with host cells. We found that adhesion, and 
invasion, of BAE cells by $N$. caninum happened in a non-homogeneous manner. Some host cells would contain several parasites, others none. Similar patterns of heterogeneous host cell attachment had been previously observed for other intracellular parasites (Schenkman, Diaz \& Nussenzweig, $1991 b$; Mineo \& Kasper, 1994). After 45-60 min, tachyzoite invasion had reached a plateau, although (i) there were still additional parasites adhering onto the endothelial cell surface and (ii) there was still a considerable number of uninfected host cells present. This suggested (i) that adhesion onto host cells did not automatically lead to penetration of the host cell membrane, and (ii) that the parasites had lost their potential to infect target cells upon prolonged extracellular maintenance. The latter assumption was confirmed by performing appropriate timecourse experiments. Tachyzoites were incubated in culture medium for different time periods before being allowed to react with BAE cells. By increasing the time of extracellular maintenance of $N$. caninum tachyzoites infectivity was dramatically reduced. It is also possible that both adhesion and infection of endothelial cells was dependent on the host cell cycle. Infection of mammalian cells by $T$. gondii for instance appeared to increase when the cells progressed from the $G 1$ phase to the $S$ phase, and decreased as the cells entered G2-M phase. Thus, it has been suggested that certain host cell surface proteins which are expressed at different times on the nost cell surface would serve as parasite receptors (Dvorak \& Crane, 1981).

The inital step of the parasite invasion process was recognition and attachment to its host cell. Electron micrographs of adherent $N$. caninum showed that tachyzoites would initially attach to BAE cells by any part of their surface. Furthermore, no preference could be seen for any specialized host cell surface domain. Parasites could interact with host cell pseudopodia as well as with the BAE cell surface devoid of pseudopodia. Tachyzoites also bound to both paraformaldehyde- and glutaraldehyde-fixed BAE cells, but attachment was much more efficient to living cells. This can be explained by considering the plasma membrane of living cells as a highly dynamic structure, with additional receptors probably engaged during incubation with the parasites. Fixation of target cells has also been used in studies on the attachment of $T$. cruzi to fibroblasts, MDCK cells and to rat heart myoblasts (Schenkman et al. $1991 a, b$; Villata et al. 1993), in studies on the interaction of $T$. congolense with endothelial cells (Hemphill et al. 1994; Hemphill \& Ross, 1995), and in studies of the adherence of $T$. gondii to human fibroblasts (Mineo \& Kasper, 1994).

$N$. caninum was not only able to adhere to, but also to invade BAE cells fixed with $3 \%$ paraformaldehyde, provided that no glutaraldehyde was used. Minute amounts of glutaraldehyde $(0.05 \%)$ com- pletely blocked penetration of BAE cells. This was probably due to the higher cross-linking ability of glutaraldehyde compared to paraformaldehyde (Griffiths, 1993). However, when viewed by TEM, the mechanisms of penetration of living and pre-fixed BAE cells appeared to be somewhat different. Invasion of live BAE cells by $N$. caninum tachyzoites was a multistep process. As the parasite encountered a suitable location for penetration of the endothelial cell surface, the host and the parasite plasma membranes bound closely to each other at the site of initial contact. A recess developed on the endothelial cell surface, and the parasite moved into the host cell with the host cell membrane curving around the invading parasite, which eventually became intracellular, completely encircled by a parasitophorous vacuole membrane. This process is likely to be very similar, but not necessarily identical, to the 'self zippering mechanism' described for the invasion of host cells by other intracellular parasites such as $T$. cruzi (Schenkman et al. 1991 a; Theileria parva (Fawcett et al. 1984), Plasmodium spp. ('Tait \& Sacks; 1988; Holder, 1994), and Toxoplasma gondii (Werk, 1985; Bonhomme et al. 1992). In contrast to this process, penetration of pre-fixed BAE cells was accompanied by extensive endothelial cell surface membrane damage. The host cell showed dramatic changes at the point of entry, with the plasmalemma being disrupted and clusters of irregular vesicles appearing around the advancing parasite. However, we could still distinguish between intra- and extracellular parasites by fluorescence staining. These findings are not all surprising since other intracellular parasites were also found to be capable of infection of paraformaldehyde pre-fixed host cells in vitro (Schenkman et al. 1991a). Thus it is possible, that tachyzoites invading pre-fixed host cells were still capable of constructing some sort of vacuole within these pre-fixed cells, which rendered them unaccessible to antibodies. However, the question whether parasites can survive and undergo endodyogeny within paraformaldehyde-treated cells will need further clarification.

Several other lines of evidence suggested that the invasion process required parasite energy and was largely independent of the target cell metabolism. Firstly, performing the adhesion assay at $4^{\circ} \mathrm{C}$ reduced the rate of both adhesion and invasion. Secondly, pre-fixed tachyzoites were not found inside living BAE cells. Thirdly, metabolic inhibition of tachyzoites using deoxyglucose, sodium azide, oligomycin and antimycin reduced the rate of both adhesion and invasion to $\mathrm{BAE}$ cells, while treatments of BAE cells with the same glycolytic and mitochondrial inhibitors affected neither adhesion nor invasion. Thus, metabolic energy was necessary to trigger invasion after an initial, probably lowaffinity, contact between parasite and host cell surface molecules. The fact that treatment of 
parasites with $\mathrm{H} 8$, an inhibitor of protein kinases, also resulted in partial inhibition of invasion, suggests that this mechanism could be mediated by rapid signal transduction events similar to those which occur after the interaction between $T$ cells and their targets (Kammer et al. 1988), or T. cruzi and MDCK-cells (Schenkman et al. 1991a). De novo protein synthesis on part of the parasite apparently did not play an important role during adhesion and invasion, since cycloheximide treatment of parasites prior to incubation with BAE cells had no effect. Based on these criteria, the adhesion / invasion process of host cells by $N$. caninum was very similar to equivalent processes described in other Apicomplexa such as Plasmodium and Toxoplasma (Tait \& Sacks, 1988). For these parasites, however, evidence has been obtained that specific target cell surface proteins serve as parasite receptors which mediate attachment to, and invasion of, host cells (Holder, 1994; Kasper \& Mineo, 1994).

Recognition of specific receptor-ligand interactions, usually mediated by cell surface adhesive molecules, is a very early process in microbial colonization and pathogenesis. In many cell types, carbohydrates are known to be crucially involved during invasive processes by parasitic microorganisms (Wilson et al. 1992; Schenkman \& Eichinger, 1993; Holder, 1994; Kasper \& Mineo, 1994). Cell surface adhesive molecules include glycolipids (Karlsson et al. 1992), glycosaminoglycans (Lander, 1993), and glycoproteins (Hoffman, 1992; Oebrink, 1993). Modifications carried out on cell surface carbohydrates would therefore be likely to influence the adhesive properties of cell surfaces. Since we experienced that modifications of carbohydrates of living cell monolayers either by chemical or enzymatic means resulted in detachment of the monolayers from the glass coverslip, we carried out these experiments only on pre-fixed BAE cells under conditions which would prevent interiorization of the parasites. We used the mildest fixation conditions possible ( $3 \%$ paraformaldehyde / $0.05 \%$ glutaraldehyde) in order to (hopefully) minimize the risk of accidentally masking or exposing cell surface receptors different from the ones which would be accessible for the parasites on unfixed cells. Periodate oxidation at acidic $\mathrm{pH}$ had previously been used as a tool to cleave carbohydrate residues (Woodward, Young \& Bloodgood, 1985; Hemphill et al. 1994). The results presented here after the use of a whole range of periodate concentrations at low and neutral $\mathrm{pH}$, show that removal of carbohydrates from the endothelial cell surface increased the adhesion of $N$. caninum tachyzoites. However, the possibility that other cell surface components were also affected by this treatment can not be ruled out.

Therefore, enzymatic treatments were performed, namely neuraminidase and hyaluronidase digestions. Both treatments of endothelial cell surfaces pro- moted the attachment of $N$. caninum tachyzoites to BAE cells. Similar results were obtained when sialic acid residues were removed from the surface of macrophages prior to infection with $T$. gondii (de Carvalho et al. 1993) and T. cruzi (Araujo-Jorge \& de Souza, 1984). In contrast, for Plasmodium spp. the situation with respect to sialic acid residues is less clear. Neuraminidase treatment of erythrocytes makes human red cells refractory to most $P$. falciparum strains, but has no effect on invasion by $P$. knowlesi (Holder, 1994). Hyaluronidase treatment of host cells also enhanced the penetration of Hela cells by tachyzoites of $T$. gondii, as previously reported by Lycke, Lund \& Strannegard (1965) and Norrby (1971), and similar results were obtained in a study investigating the interaction of macrophages with $T$. gondii (de Carvalho et al. 1993). It is likely that removal of sialic acid residues and acid mucopolysaccharides facilitates the interaction of surface components of parasite and host cells participating in the interaction.

The role of potential carbohydrate residues on the $N$. caninum cell surface in adhesion to, and invasion of, BAE host cells, was also assessed. Parasites were treated either with sodium periodate or with tunicamycin prior to incubation with host cells. Neither of these treatments had any effect. However, the reduction in adherence and invasion after protease treatment of tachyzoites suggested that removal of proteins or protein fragments from the parasite surface also removed, or altered, the molecules responsible for mediating $N$. caninum interaction with the monolayer. It is likely that this interaction involved specific molecules that would act as ligands mediating host-cell recognition and invasion.

Receptor-ligand systems employing mainly glycoproteins, glycolipids and lectin binding sites, have been shown to be responsible for parasite adhesion and invasion in Trypanosoma, Plasmodium and Toxoplasma. The interaction between $T$. cruzi and mammalian host cells for instance involves probably multiple parasite ligands. The glycoprotein $\mathrm{gp} 83$, isolated from $T$. cruzi trypomastigote membranes, is one of those ligands mediating parasite attachment (Villata et al. 1992, 1993). Furthermore, a $60 \mathrm{kDa}$ surface protein (Ortega-Barria \& Pereira, 1992), as well as the ssp3 antigen of $T$. cruzi (Schenkman et al, 1992) have been reported to be involved in adhesion and invasion of mammalian cells. On the other hand, a $74 \mathrm{kDa}$ cell surface receptor on rat heart myoblast has been identified, and this glycoprotein appears to serve as a mammalian trypanosome receptor (Vilatta et al. 1992). P. falciparum is known to infect erythrocytes by binding onto the transmembrane glycoprotein band 3 (Donelson \& Fulton, 1992). However, binding of this parasite to its target cells is completely inhibited in the presence of BSA-Nacetyl-glucosamine, suggesting that the ligand on the Plasmodium surface exhibits lectin-like properties 
with a high affinity for sialic acid residues. The current literature on $T$. gondii adhesion to host cells underlies the importance of three points. Firstly, tachyzoites possess surface ligands which bind the ECM protein laminin with high affinity; parasitebound laminin then promotes the attachment of the tachyzoites to the host cell laminin receptor. Secondly, lectins are known to mediate cell-cell interactions. BSA-glucosamide, albumin- $N$-acetyl-Dglucosamine and albumin-galactose bound to extracellular tachyzoites. Electron microscopical studies with gold-labelled lectins and glycoproteins localized sugar residues on parasite rhoptries, but not on the surface. Thus it was proposed that sugar containing macromolecules are released upon contact with the host cell membrane (Kasper \& Mineo, 1994). Thirdly, it has been shown that the major surface antigen of $T$. gondii (SAG-1, P30) is involved in parasite attachment and invasion (Mineo \& Kasper, 1994). Also non-invasive protozoan parasites adhere to their host cells via carbohydrate residues. For instance, Giardia duodenialis adhesion to intestinal epithelial cells is apparently mediated by cell surface lectin-binding sites (Pegado \& deSouza, 1994). Lectin-mediated cell-cell interactions are also important during the pathogenesis of African animal trypanosomiasis caused by $T$. congolense (Hemphill et al. 1994; Hemphill \& Ross, 1995). Terminal carbohydrates have also recently been shown to play a crucial role during the cytoadherence of Trichomonas vaginalis and Tritrichomonas foetus (Bonilha et al. 1995). However, there is no information either on $N$. caninum ligands or on host cell receptors which could potentially be involved in adhesion to, or invasion of, target cells by this parasite.

The cytoskeleton in most eukaryotic cells is involved in cellular events such as cell motility and surface receptor movements (Geiger, 1989). We therefore assessed the effects of cytoskeletal drugs on adhesion and invasion of BAE cells by $N$. caninum tachyzoites. We treated parasites with drugs which would specifically affect microtubules and actin microfilaments. Treatment of both parasites and BAE cells with taxol and nocodazole, which are microtubule-active drugs in higher eukaryotic cells, had no effect either on adhesion or on invasion. However, pre-treatment of tachyzoites with cytochalasin $\mathrm{D}$ were very effective. This drug has been shown to inhibit the endocytotic process, to prevent plasma membrane extensions, and is known to cause redistribution of cell surface receptors which are physically linked to the cortical actin skeleton (Cooper, 1987; Geiger, 1989). In the present study it significantly inhibited the invasive capacities of $N$. caninum. Similar results were obtained previously with T. gondii (Ryning \& Remington, 1978; Sibley, 1995). For this parasite, morphological studies had revealed changes in the parasite during entry such as screw movements, extension of the apical pole, rotating movements and amoeboid deformation. An actin-myosin system has been localized in the apical complex using specific antibodies (Schwarzman \& Pfefferkorn, 1983; Endo et al. 1988), and this has been implicated in invading movements. Thus, similar actin-myosin based movements are likely to be involved during penetration of host cells by $N$. caninum.

BAE cell monolayers were also treated with cytochalasin D. Treatment of BAE cells with this drug prevented invasion by $N$. caninum. This is not surprising since inhibition of invasion had been previously observed with respect to the interaction of T. gondii (Ryning \& Reminton, 1978; Silva, Meirelles \& de Souza, 1982; de Carvalho et al. 1993), and T. cruzi (Henriquez, Piras \& Piras, 1981 ; Zenian \& Kierszenbaum, 1983) with macrophages. However, at the same time the number of $N$. caninum tachyzoites which adhered to the host cell surface was significantly higher than in control experiments. This effect clearly demonstrated that adhesion and invasion are two distinct processes. While, after cytochalasin D treatment, the parasites could still adhere to the host cells, the signal(s) which would trigger the invasive process within the parasite was (or were) not present anymore, probably altered or dislocated upon cytochalasin $\mathrm{D}$ treatment. Thus, the identification and characterization of molecules, on both the host cell surface and the parasite surface, which are responsible for mediating such signals, will be a primary goal during future investigations.

In conclusion, our studies have provided important basic information on the interaction between $N$. caninum and BAE cells. Our experiments demonstrated the ultrastructural aspects, as well as the kinetics of parasite atttachment, invasion, and intracellular development in vitro. Biochemical treatment using metabolic inhibitors showed that adhesion and invasion are active processes which require metabolic energy on the part of the parasite, but not on the host cells. Chemical and enzymatic modifications of both BAE cell and parasite surface have demonstrated that the initial contact between the parasites and BAE cells is a receptor-mediated process, unlikely to be mediated by carbohydrates. However, adhesion and penetration of the host cell membrane are two distinct events; the latter one probably mediated by cell surface molecules which are physically linked to the cortical actin skeleton of both $N$. caninum and BAE cells. These investigations provide the basis for further ongoing studies on the identification and characterization of host cell receptors and $N$. caninum ligands which play important roles during Neosporosis.

The $N$. caninum isolate $\mathrm{Nc}-1$ was a kind gift from J. P. Dubey (US Department of Agriculture, Beltsville, MD) and Joakim Hohmdahl (Swedish University of Agricultural Sciences, Uppsala). We are grateful to Carole Ross (Centre for Tropical Veterinary Medicine, Uni- 
versity of Edinburgh, Scotland) for her gift of BAE cells Giovanni Rossi (Institute for Veterinary Pathology, University of Berne) for letting us perform ultramicrotomy in his laboratory, and Toni Wyler (Insitute for Zoology, University of Bern) for his help with electron microscopy and photography. We thank Norbert Mueller and Richard Felleisen for stimulating discussions and critical comments on the manuscript. Many thanks also to Olivier Flechtner and Mat Yamage for help with cell culturing, and Vreni Zimmermann for technical assistance. Extensive moral support was provided by Banu Yuerueker. This project was supported by the Bundesamt fuer Veterinaerwesen (Switzerland).

\section{REFERENCES}

ARALJIO-JORGE, T. C. \& DE SOLZA, W. (1984). Interaction of Trypanosoma cruzi with macrophages: effect of previous incubation of the parasites or host cells with lectins. Zeitschrift für Parasitenkunde 72, 153-71.

AUGtSTINE, P. C. (1989). The Eimeria: cellular invasion and host-cell parasite interactions. In Coccidia and Intestinal Coccidiomorphs. Collogues de INTRA 49, (ed. Yvore, P.) pp. 205-215. Tours, France.

BANNISTER, L. H. \& DLUZEWSKI, A. R. (1990). The ultrastructure of red cell invasion in malaria infections: a review. Blood Cell 16, 257-92.

BARR, B. C., ROWE, J. D., SVERLOV, K. W., BON DURANT, R. H., ARDANS, A. A., OLIVER, M. N. \& CONRAD, P. A. (1994). Experimental reproduction of bovine fetal Neospora infection and death with a Neospora isolate. Yournal of Veterinary Diagnostic Investigations 6, 207-15.

BONHOMME, A., PINGRET, L. \& PINON, J. M. (1992).

Review: Toxoplasma gondii cellular invasion.

Parassitologia 34, 31-43.

Bonilha, v. L., do Carmo ciavaglia, M., de souza, w. * E SILVA FILHO, F. C. (1995). The involvement of terminal carbohydrates of the mammalian cell surface in the cytoadhesion of trichomonads. Parasitology Research 81, 121-6.

CHOBOTAR, B., DANFORTH, H. D. \& ENTZEROTH, R. (1993). Ultrastructural observations of host cell invasion by sporozoites of Eimeria papillata in vivo. Parasitology Research 79, 15-23.

COOPER, J. A. (1987). Effects of cytochalasin and phalloidin on actin. Fournal of Cell Biology 105, 1473-8.

CROSS, G. A. M. TACKLE, G. B. (1993). The surface transsialidase family of Trypanosoma cruzi. Annual Reviews in Microbiology 47, 385-411.

DE CARVAlHo, L., YAN, C. Y. I. \& DE SOUZa, W. (1993).

Effect of various digestive enzymes on the interaction of Toxoplasma gondii with macrophages. Parasitology Research 79, 114-18.

DONELSON, J. E. \& FULTON, A. B. (1992). Skirmishes on the border. Nature (London) 356, 480-1.

DUBEY, J. P., CARPENTER, J. L., SPEER, A., TOPPER. M. J. \& UGGLA, A. (1988). Newly recognized fatal protozoan disease of dogs. Fournal of the American Veterinary Medicine Association 198, 1269-85

DUBEY, J. P. \& LINDSAY, D. S. (1993). Neosporosis. Parasitology Today 9, 452-8

DVORAK, J. A. \& CRANE, M.S. J. (1981). Vertebrate cell cycle modulates infection by protozoan parasites. Science 214, 1034-6.

ELLIS, J., LUTON, K., BAVERSTOCK, P. R., BRINDLEY, P. J., Nimmo, K. A. \& JoHsson, A. M. (1994). The phylogeny of Neospora caninum. Molecular and Biochemical Parasitology 64, 303-11.

ENDO, T., YAGITA, K., YASLDA, T. \& NAKAMURA, T. (1988). Demonstration and localization of actin in Toxoplasma gondii. Parasitology Research 75, 102-6.

FAWCETT, D., MUSOKE, A. \& VOIGT, W. (1984). Interaction of sporozoites of Theileria parva with bovine lymphocytes in vitro. 1. Early events after invasion. Tissue and Cell 16, 873-84.

GEIGER, B. (1989). Cytoskeleton associated cell-contacts. Current Opinion in Cell Biology 1, 103-9.

GRAY, M. A., ROSS, C. A., TAYLOR, M. A., TETLEY, L. \& LLCKINS, A. G. (1985). In vitro cultivation of Trypanosoma congolense: the production of infective forms of metacyclic trypanosomes cultured on bovine aorta endothelial cell monolayers. Acta Tropica 42, 99-110.

GRIFFITHS, G. (1993). Fixation for fine structure preservation and immunocytochemistry. In Fine Structure Immunocytochemisty (ed. Griffiths, G), pp. 26-89. Heidelberg: Springer Verlag.

HEMPHILL, A., AFFOLTER, M. \& SEEBECK, T. (1992). A novel microtubule binding motif identified in a high molecular weight microtubule-associated protein from Trypanosoma brucei. Journal of Cell Biology 117, 95-103.

HEMPHILL, A., FRAME, I. \& ROSS, C. A. (1994). 'The interaction of Trypanosoma congolense with endothelial cells. Parasitology 109, 631-41.

HEMPHILL, A. \& ROSS, C. A. (1995). Flagellum-mediated adhesion of Trypanosoma congolense to bovine aorta endothelial cells. Parasitology Research 81, 412-20.

HENRIQLEZ, D. R., PIRAS, R. PIRAS, M. M. (1981). The effect of surface membrane modification of fibroblastic cells on the entry process of Trypanosoma cruzi trypomastigotes. Molecular and Biochemical Parasitology 2, 359-66.

hoffma., s. (1992). Assays of cell adhesion. In Cell-Cell Interactions. A Practical Approach. (ed. Rickwood, D. \& Hames, B. D.), pp 1-29. London: IRL press. HOLDER, A. A. (1994). Proteins on the surface of the malaria parasite and cell invasion. Parasitology 108, S5-S18.

JoINER, K. A. DUBREMETZ, J. F. (1993). Toxoplasma gondii: a protozoan for the nineties. Infection and Immunity 61, 1169-72.

KAMMER, G. M., BOEHM, C. A., RUDOLPH, S. A. SCHULTZ, L. A. (1988). Mobility of the human T lymphocyte surface molecules CD3, CD4, CD8: regulation by a cAMP-dependent pathway. Proceedings of the National Academy of Sciences, USA 85, 792-6.

KARLSSON, K. A., MILH, M. A., ANGGSTROEM, J., BERGSTROEM, J., DEZFOOLIAN, H., LANNE, B., LEONARDSON, I. \& TENEBERG, S. (1992). Membrane proximity and internal binding in the microbial recognition of host cell glycolipids: A conceptual discussion. In Molecular Recognition in Host-Parasite Interactions. FEMS Symposium No. 61. (ed. Korhonen, T. K., Hovi, T. \& Maekelae, P. H.), pp.115-132. New York: Plenum Press. 
KASPER, L. H. \& MINEO, J. R. (1994). Attachment and invasion of host cells by Toxoplasma gondii.

Parasitology Today 10, 184-8.

LANDER, A. D. (1993). Proteoglycans. In Guidebook to Extracellular Matrix and Adhesion Proteins. (ed. Kreis, T. \& Vale, R.), pp. 12-16. Oxford: Oxford University Press.

LINDSAY, P. S. \& DUBEY, J. P. (1989). In vitro development of Neospora caninum (Protozoa: Apicomplexa) from dogs. Fournal of Parasitology 75, 163-5.

LiNdSAY, D. S., BlagbURN, B. L. \& DUBEY, J. P. (1990). Infection of mice with Neospora caninum (Protozoa: Apicomplexa) does not protect against challenge with Toxoplasma gondii. Infection and Immunity 58, 2699-700.

LINDSAY, D. S., SPEER, C. A., TOIVIO-KINNUCAN, M. A., DUBEY, J. P. \& BLAGBURN, B. L. (1993). Use of infected cultured cells to compare ultrastructural features of Neospora caninum from dogs and Toxoplasma gondii. American Fournal of Veterinary Research 54, 103-6.

LYCKE, E., LCND, E. \& STRANNEGARD, O. (1965).

Enhancement by lysozyme and hyaluronidase of the penetration by Toxoplasma gondii into cultured host cells. British Journal of Experimental Pathology 46, 189-99.

MINEO, J. R. \& KASPER, L. H. (1994). Attachment of Toxoplasma gondii to host cells involves major surface protein SAG-1 (P30). Experimental Parasitology 79. 11-20.

NORRBY, R. (1971). Immunological study on the host cell penetration factor of Toxoplasma gondii. Infection and Immunity 3, 278-86.

OEBRINK, B. (1993). Cell adhesion and cell-cell contact proteins. In Guidebook to the Extracellular Matrix and Adhesion Proteins (ed. Kreis, T. \& Vale, R.), pp. 109-114. Oxford: Oxford Liniversity Press.

Ortega-barria, E. \& PereirA, M. E. A. (1992). A novel $T$. cruzi Theparin-binding protein promotes fibroblast adhesion and penetration of engineered bacteria and trypanosomes into mammalian cells. Cell 67, 411-21.

PASVOl, G., CARlsson, J. \& Clough, B. (1992).

Recognition of molecules on red cells for malarial parasites. In: Molecular Recognition in Host-Parasite Interactions. FEMS Symposium No. 61, (ed. Korhonen, T. K., Hovi, T. \& Maekelae, P. H.), pp. 173-200. New York: Plenum Press.

PEgADO, M. G. F. \& DE souzA, W. (1994). Role of surface components in the process of interaction of Giardia duodenialis with epithelial cells in vitro. Parasitology Research 80, 320-6.

RYNING, F. W. REMINGTON, J. S. (1978). Effect of cytochalasin D on Toxoplasma gondii cell entry. Infection and Immunity 20, 739-43.

SCHENKMAN, s. EICHINGER, D. (1993). Trypanosoma cruzi trans-sialidase and cell invasion. Parasitology Today 9, 218-22.

SCHENKMAN, S., KURASAKI, T., RAVETCH, J. V. NUSSENZWEIG, v. (1992). Evidence for the participation of the ssp3 antigen in the invasion process of nonphagocytic mammalian cells by Trypanosoma cruzi. Yournal of Experimental Medicine 175, 567-75.

SCHENKMAN, S., ROBBINS, E. S. \& NUSSENZWEIG, v. (1991 a). Attachment of Trypanosoma cruzi requires parasite energy and invasion can be independent of the target cell cytoskeleton. Infection and Immunity 59, 645-54.

SCHENKMAN, S., DIAZ, C. \& NUSSENZWEIG, v. (1991b). Attachment of Trypanosoma cruzi trypomastigotes to receptors at restricted cell surface domains. Experimental Parasitology 72, 76-86.

SCHWARzMAN, J. PFEFFERKORN, E. R. (1983). Immunofluorescent localization of myosin at the anterior pole of coccidian Toxoplasma gondii. Fournal of Protozoology 30, 657-61.

SEEFELDT, S. L., KIRKBRIDE, C. A. \& DUBEY, J. P. (1989). Comparison of enzyme-linked immunosorbent assay, direct fluorescent antibody test, and direct agglutination test for detecting Toxoplasma gondii antibodies in naturally aborted ovine fetuses. Journal of Veterinary Diagnostical Investigations 1, $124-7$.

SHAW, M. K., TILNEY, L. G. MUSOKE, A. J. (1991). The entry of Theileria parva sporozoites into bovine lymphocytes: evidence for MHC class I involvement. Yournal of Cell Biology 113, 87-101.

SIBLEY, D. L. (1995). Invasion of vertebrate cells by Toxoplasma gondii. Trends in Cell Biology 5, 129-33.

SILVA, S. R. L., MEIRELLES, S. R. L. \& DE SOUZA, W. (1982). Mechanism of entry of Toxoplasma gondii into vertebrate cells. Journal of Submicroscopical Cytology 14, 471-82.

SMITH, M. \& CROFT, s. L. (1991). Embedding and thin section preparation. In Electron Microscopy in Biology. A Practical Approach. (ed. Rickwood, D. \& Harris, B. D), pp. 17-37. London: IRL Press.

TAIT, A. \& SACKS, D. L. (1988). The cell biology of parasite invasion and survival. Parasitology Today 8, 228-34.

TREes, A. J., TENNANT, B. J. \& Kelly, D. F. (1991). Paresis in dogs and Neospora caninum. Veterinary Record 129, 456.

Villata, F., Lima, M. F., RUIZ-RUANo, A. zHOU, 1. (1992). Attachment of Trypanosoma cruzi to host cells: a monoclonal antibody recognizing gp83 which is required for parasite attachment. Biochemical and Biophysical Research Communications 182, 6-13.

villatA, F., RUIz-RUANo, A., VAlENTINe, A. A. \& LiMA, M. F. (1993). Purification of a $74 \mathrm{kDa}$ glycoprotein from heart myoblasts that inhibits binding and entry of $T$. cruzi into heart cells. Molecular and Biochemical Parasitology 61, 217-30.

WERK, R. (1985). How does Toxoplasma gondii enter host cells? Reviews of Infectious Diseases 7, 449-57.

WILSON, M. E., DONELSON, J. E., PEARSON, R. D. \& RAMAMOORTHY, R. (1992). Macrophage receptors and Leishmania. In: Molecular Recognition in Host-Parasite Interactions. FEMS Symposium No. 61, (ed. Korhonen T. K., Hovi, T. \& Maekelae P. H.), pp. 17-30. New York: Plenum Press.

WOODWARD, M. P., YOUNG, W. W. \& BLOODGOOD, J.R. (1985). Detection of monoclonal antibodies specific for carbohydrate epitopes using periodate oxidation. Fournal of Immunological Methods 78, 143-53. zenian, A. \& KIERSzenbaUM, F. (1983). Trypanosoma cruzi: Differences in cell surface interaction of circulating (trypomastigote) and culture (epimastigote) forms with macrophages. Journal of Parasitology 69, $660-5$. 